\title{
Implementation of the Millennium Development Goals in Nigeria through Non-Formal Education Curriculum
}

\author{
Akpama, Simon Ibor, Asor, Love Joseph \& Erim, Costly M \\ Department of Adult and Continuing Education \\ University of Calabar, Calabar, Nigeria \\ E-mail: akpama2008@yahoo.com \\ Adekola, G. \\ Department of Adult and Non-Formal Education \\ University of Port Harcout, Port Harcourt, Nigeria \\ Tel: 23-480-6469-8589Ｅ-mail: adekolag@yahoo.com
}

Received: August 3, 2011 Accepted: August 18, 2011 Published: March 1, 2012

doi:10.5539/hes.v2n1p11

URL: http://dx.doi.org/10.5539/hes.v2n1p11

\begin{abstract}
Nigeria is a signatory to the Millennium Development Goals (MDGs) declaration but till now she has not made any significant milestones in actualizing these human development goals. In spite of the coordinated efforts towards mobilizing those in the formal education system to partially address its implementation challenges, serious gaps still exit in the implementation drive through the non-formal education. Most adults whose position and daily activities are critical to the successful actualization of the MDGs are excluded from the implementation programmes. Against this backdrop, this paper explores the relevance of non-formal education curriculum to the actualization of the Millennium Development Goals in Nigeria within the 2015 time frame.
\end{abstract}

Keywords: Millenium development goals, Non-formal education curriculum

\section{Introduction}

In the September 2000 United Nations General Assembly session, 189 nations including Nigeria resolved and committed themselves to combat poverty and other development challenges to expedite development for everyone through a declaration of the United Nation Millennium Development Goals (MDGs). They decided that these set of goals could assist to "free all men, women and children from the clutches of abject poverty and other dehumanizing conditions in human settlements by the year 2015 (Economic commission for Africa 2005, 2006, \& Fasokun, 2008).

Precisely, halving by the years 2015 , the number of people who live on less than one dollar a day. The Assembly called on member nations to proffer enduring solutions to the problems of hunger, malnutrition, and disease. They stressed that immediate measures must be adopted to promote gender equality and the empowerment of women, guarantee basic education for all, and support the principles of sustainable development and global partnership for development. The year 2015 was set for all member nations to actualize these lofty human development goals. In order to help developing nations to fast track the implementation of these goals, the developed and richer countries of the world committed themselves to assisting developing countries in the form of aid, trade, debt relief, and investment. Achieving Millennium Development Goals (2005) \& Fasokun (2008).

For the purpose of implementation of the Millennium Development Goals, the adult populations constitute the target audience and medium. Therefore, it ibecomes imperative to employ adult and non-formal education based strategies to elicit and sustain the involvement of these adults, on whose active participation the actualization of the Millennium Development Goals depends. It is on this premise that this paper explores the relevance of non formal education curriculum to the implementation of the Millennium Development Goals in Nigeria.

\section{Millennium Development Goals and Their Targets}

The millennium development goals could be described as a human rights approach to development with ardent emphasis on equality and non-discrimination. This point corroborate Biao (2008) assertion that the maintenance of a life-sustaining environment forms the main fulcrum around which this human development agenda revolves. Each 
goal has a definite target and indicators explicitly spelt out as a basis to evaluating the achievements of each of the Millennium Development Goals.

Fasokun (2006) and Biao (2008) listed the Millennium Development Goals and their targets as highlighted below:

Goal 1: $\quad$ Eradicate extreme poverty and hunger

Targets : $\quad H a l v e$, between 1990 and 2015, the proportion of people whose income is less than one dollar a day. Halve, between 1990 and 2015, the proportion of people who suffer hunger

Goal 2: $\quad$ Achieve universal primary education

Target: $\quad$ Ensure that, by 2015 , children every where, boys and girls alike, will be able to complete a full course of primary schooling

Goal 3: $\quad$ Promote gender equality and empower women

Target: $\quad$ Eliminate gender disparity in primary and secondary education, preferably by 2005 , and at all levels of education not later than 2015

Goal 4: $\quad$ Reduce child mortality

Target: $\quad$ Reduce by two-thirds, between 1990 and 2015, the under five mortality rate

Goal 5: $\quad$ Improve maternal health

Target: $\quad$ Reduce by three-quarters, between 1990 and 2015, the maternal mortality ratio

Goal 6: $\quad$ Combat HIV/AIDs, malaria and other diseases

Targets: Have halted by 2015 and began to reverse the spread of HIV/AIDs.

Have halted by 2015 and began to reverse the incidence of malaria and other major diseases.

Goal 7: $\quad$ Ensure environmental sustainability

Targets: Integrate the principle of sustainable development into country policies and programmes and reverse the loss of environmental resources

Halve, by 2015, the proportion of people without sustainable access to drinking water.

By 2020, to have achieved a significant improvement in the lives of at least 100 million slum dwellers.

Goal 8: $\quad$ Develop a global partnership for development

Targets: Develop further an open, rule-based, predictable non-discriminatory trading and financial system (includes a commitment to good governance, development and poverty reduction-both nationally and internationally)

Address the special needs of the least developed countries (LDC). (includes: tariff and quota free access for LDC exports, enhanced programme of debt relief for HIPC and cancellation of official bilateral debt, and more generous ODA (Overseas Development Assistance) for countries committed to poverty reduction.

Address the special needs of landlocked countries and small Island developing states (though the programme of action for the sustainable development of small Island Developing states and the outcome of the $22^{\text {nd }}$ special session of the General Assembly).

Deal comprehensively with the debt problems of developing counties through national and international measures in order to make debt sustainable in the long term.

In co-operation with developing countries, develop and implement strategies for decent and productive work for youth.

In co-operation with pharmaceutical companies, provide access to affordable, essential drugs in developing countries, provide access to affordable essential drugs on a sustainable basis

In co-operation with the private sector, make available the benefits of new technologies, especially information and communications.

These goals and their targets indicates the development levels that countries of the world (especially the third world countries) plan to be by the year 2015. As a result all hands must be on deck to ensure achievement of these goals especially in African countries where the progress report is not favourable for now. 


\section{Concept of Non-Formal Education}

Non-formal education (NFE) is a world wide phenomenon systemic out-of-school activities designed to meet specific needs which are to be found in both developed and developing countries. In most cases, non-formal education programmes are designed to serve people who are currently not participating in school education or those who could not receive sufficient education in the past, consisting of both adults and children. For example non-formal education activities can range from literacy education, to vocational training and the provision and modalities of learning can vary from a community-based literacy class to distance and nomadic education. Viewed from this perspective, Coombs and Ahmed (1974:8) defined non-formal education as any organized educational actively outside the established formal system-whether operating separately or as an important feature of some broader activity- that is intended to serve identifiable clienteles and learning objectives. The thrust of this definition is on the distinction between formal and non-formal education as different modes of addressing the learning needs of identified group of people.

However, a recent study by UNESCO (2006) substantiated this definition in recognition of contexts and focus on the human rights agenda for education; although according to Preece (2009) there is a suggestion that this kind of provision is based on perception of deficit rather than being accorded equal status with the formal system. In UNESCO's (2006:39) definition NFE is:

...based on an integrated approach that takes into account all the factors influencing the opportunities and life chances of different population groups and the role played by education systems themselves in the process of social inclusion and cohesion... (it is) learning embedded in planned, organized and sustained education activities that are outside formal education institution (sic), responding to education needs for all persons of all ages. The purpose of NFE is to provide alternative learning opportunities for those who do not have access to formal schooling or need specific life skills and knowledge to overcome different obstacles. Non-formal learning is also intentional from the learner's point of view as opposed to incident or random types of learning.

Based on this conceptualization, Kleis (1974) cited in Ngwu (2003:14) described non formal education as:

an intentional and systematic enterprise (usually outside of traditional schooling) in which content, media, units, admission criteria, staff, facilities and other system components are selected and/or adapted for particular students, populations or situations in order to maximize attainment of the learning mission and minimize maintenance constraints of the system.

The nature of non-formal education described by Kleis is selective, flexible and has commendable potentials for serving divergent needs of various groups and a variety of situations.

Furthermore, from a process standpoint Harbison (1973:80) states that non-formal education and training entail the total range of learning processes and experiences dispensed outside the conventional and graded school system. It encompassed learning from parents communication with others and learning from experience to formal training on the job, apprenticeship, adult education, and participation in organized out-of-school programmes such as youth brigades, extension services, community development projects, and health and family planning clinics.

From a functional dimension Bhola (1980) observed that non-formal education comprised of any organized educational or training activity for school drop-out, for illiterate rural and urban adults, for youth, for women or for industrial workers whose aim is to improve employment and income generating opportunities or give its clientele general education to enhance re-entry into the formal school system.

This comprehensive definition captures vividly the realities of non-formal education in the developing world. Its emphasis on the type of clientele, training, production and creation of income generating opportunities makes it relevant to the contemporary poverty alleviation focus of current non-formal education programmes in Nigeria. Thus, non-formal education could be viewed as an alternative system to formal education meant to serve identifiable clientele comprising those for one reason or the other who did not benefit from formal education (Azikiwe,1992 \& Akintayo and Oghenekohwo, 2006).

As a function and process Ngwu (2003) sees NFE as an organized educational activity outside the established formal school educational system to serve identifiable learners and learning outcome. It is flexible in terms of location, time, materials, methods, learners and providers (Akintayo, 2004) and so it is any organized systematic educational activity carried out outside the framework of the formal system to provide selected types of learning to particular sub-groups in the population, adults as well as children.

A synthesis of these definitions as noted by Ngwu (2003:18) depict non-formal education as: 
any planned, consciously organized general education and/or training activity outside the formal school in a particular society for illiterates, school leavers, drop outs or other adults, as individuals or in groups, for the purpose of raising the consciousness of their social situation and their standard of living, improving their individual or collective efficiency in their jobs or preparing them for self-employment, wage employment or further training within the existing education/learning system.

This conceptualization of non-formal education informed the 1990 Jometien Declaration on education for all where non formal basic education is integrated into the institutional framework of a national learning system in such a manner as to enable school drop outs and self-employed workers in the informal sector to achieve the basic education required to facilitate their re-entry into the formal school system (Ngwu, 2003).

It must be noted that from whichever perspective the concept of non-formal education is viewed, it is a human development strategy for an identifiable group of persons located outside the formal education system. It could be inferred from this array of definitions that non-formal education is becoming systematically ambiguous and its full meaning can better be construed within the context of its characteristics as highlighted by Ngwu (1987) cited in Akintayo et al (2006:163) to include among others that:

- Non-formal education is essentially practiced, a process of learning by doing

- Non-formal education is usually focused on a specific knowledge or skill, which is needed. As such it deals with modular units of learning designed for identifiable problems/needs.

- Non-formal education processes are flexible and non-time discriminatory;

- The emphasis is on direct learning experience;

- Location of learning is learner-friendly

- It facilitates a close relationship between skills, motivation and practice and

- It is cost effective and learner centred.

In terms of its objectives, contents, clientele, methodologies and evaluation, non-formal education is seen as flexible, not rigid and distinct as it takes cognizance of the learners, knowledge, skill, practice, process and outcomes in practice (Akintayo and Oghenekohwo 2006:163). The NFE system has been seen both as a radical and better alternative to the formal system (Illich, 1973; 1972, UNESCO; Preece, 2009) but also adjudged as an inferior form of schooling that merely accommodates education crisis until the formal system can be improved. The NFE debate could be traced to the 1960s and 1970s within the context of education in developing countries as a response to the modernization agenda for development (Rogers, 2004 \& Preece, 2009).

However, the NFE attributes of flexibility, informal nature, part-time and learner-led curriculum lends credence to it, as an appropriate strategy for the implementation of the Millennium Development Goals. According to Fasokun (2005) the scope of non-formal education covers different aspects of life and fields of knowledge as shown in this simplified schema:

\section{Schema on Scope/Forms of Adult and Non-Formal Education}

Insert Figure 2 in here.

A careful examination of the schema of non-formal education shows its rich and diverse programmes which make it a relevant tool for the implementation of the Millennium Development Goals especially as it affects adults whose roles are crucial for its implementation. The relevance of the non-formal education system within the framework of the objectives of the millennium development agenda forms the trust of this discourse.

\section{Roles of Adults in the Implementation of the Millennium Development Goals, through Non-Formal Education}

The above schema of non-formal education reveals that it has a body of knowledge, skills and needs of learners which according to Akpama and Arikpo (2002) should constitute major ingredients of curriculum contents of any learning activity. This implies that a non-formal education curriculum should revolve around the needs of the beneficiaries.

A critical analysis of the Millennium Development Goals shows that most of the goals are focused on the adult populations, thus the extent to which this goals would be achieved by 2015 is related to the knowledge and activities of the adult population now and in the future. For instance, in Goal 1 which emphasizes eradication of extreme poverty and hunger: The target audience is the adult population of the society. In fact, it is the adults who must harness available resources to conquer poverty and subsequently eradicate hunger. Therefore, through non-formal 
education programmes such as Vocational education, empowerment programmes, capital formation and loan utilization, co-operative education etc adults could be equipped with requisite knowledge and skills for the actualization of this goal.

\section{Goal 2 focuses on achieving universal primary education}

For this goal to be achieved especially as it affects the enrolment of children in formal schooling, parents and/or guardians of these children must be sufficiently conscientised and mobilized to financially and materially support these programmes since parental participation is a critical factor for the achievement of the goals of any education programme (Akpama, 2000 \& Biao, 2008). As observed by Jayne (1999) educated parents are more likely to send their children and wards to school and produce educated children; there is therefore the need to encure that the adult population come out of the problem of illiteracy by providing them literacy education which is an aspect of non-formal education.

\section{Goal 3 seeks to promote gender equality and empower women}

The adult population especially women, are the main target of this goal. Since according to Biao (2008) adult, unlike children can draw a functional distinction between the sexes, through the medium of non-formal education programmes, such as education for living, political empowerment, economic empowerment, women education etc, adults would be helped to provide resources and opportunities to ensure gender equality and empowerment of women. This strategy is important since according to Chambers (1998) women are caught in a deprivation trap consisting of five independent dimensions: lack of basics that support life, physical weakness, isolation, vulnerability, and powerlessness. Akin to these dimensions are unequal distribution of knowledge and unequal access to development assistance, power, status and wealth within individuals, gender groups, communities and religions. Nwabuko, 2006 and Labonte 1998; cited in Adewale (1998) observed that non-formal education has the potentials to democratize education and development thus give everybody equal opportunity for being educated and developed.

\section{Goal 4 aims at reducing child mortality}

Adults who are adequately equipped with relevant information and skills can help reduce child mortality. Non-formal education programmes such as child care education, reproductive health education and family life education which equip the adult population with knowledge of child spacing, immunization programmes etc are relevant non-formal education programmes useful to men and women for the actualization of this goal.

\section{Goal 5 advocates the improvement in material health}

Educating adult men and women through relevant non-formal health education programmes such as family planning and reproductive health education can help adults play requisite roles in the improvement of maternal health.

\section{Goal 6 seeks to combat HIV/AIDs, malaria and other diseases}

Awareness creation, through non-formal education on the causes of diseases, prevention and curative methods of existing diseases have been found to be efficacious by most development agents. One of the most fundamental causes of HIV/AIDs, malaria and other diseases has been traced to lack of information by parents (United Nations, 2001, \& Nwabuko, 2006) Educating parents (adults) on issues which bother on diseases through non-formal education programmes such as education for living, community health education, HIV/AIDS education and enlightenment campaign can help expedite the process of combating deadly diseases like HIV/AIDS and Malaria.

\section{Goal 7 aims at ensuring environmental sustainability}

Adults live, interact with and exploit the resources of the environment. Adults dictate how environmental resources are harnessed. There is therefore the need to sensitize the adults to the imperatives of sustainable utilization of the over degraded environment. Education programmes such as environmental adult education and education for sustainable development could be relied on to educate adults on how their day-to-day socio-economic activities impact on the environment and how they can conduct such activities in such a way that it does little or no damages to the environment.

\section{Goal 8 seeks to ensure development of global partnership}

This goal could be actualized by equipping adults with relevant information and tools since choice of development partners and tools for such development is the responsibility of adults. Non-formal education on the issues of globalization and development partnership can help facilitate the actualization of this goal.

It is evident that adults who form the main target for the actualization of the Millennium Development Goals must be adequately equipped if they (adults) must play significant role in achieving these laudable goals within the set 
time frame of 2015. Inarguably, if non-formal education programmes are properly streamlined, it could be made to directly accommodate activities and action programmes of the MDGs, even if this may require a curriculum re-design or review.

\section{Non-Formal Education Curriculum Contents for Implementation of the Millennium Development Goals}

Non-formal education which has been widely accepted as a viable alternative to the formal school system has undergone some modifications after the development of the first three UNICEF-FGN curricula contents. The latest entries according to Biao (2006) are the main concerns of the United Nations Millennium Development Goals.

Non-formal education curricula encompass 12 major areas of knowledge and training. These include basic literacy, post literacy, functional literacy, women education, nomadic education, literacy for the blind, workers education, Arabic integrated literacy, vocational education, literacy education for the disabled and prison education. Other curriculum areas which could be relevant to the implementation of the MDGS include environmental education, family health education, capital formation and loan utilization, community development and so on.

The afore listed knowledge areas have curriculum contents which are germane to the implementation of the Millennium Development Goals. The proposed curriculum design could follow the content of appendix 1

It must be stated that the collaborative efforts of adults, governments and development agencies are required to implement and bring the contents oftable 1 into fruition. To simplify the contents of table 1, a non-formal education curriculum model could be derived from table 1 as shown in appemdix 2.

The model in appendix 2 graphically depicts the Millennium Development agenda and its goals, knowledge areas, NFE curriculum contents, implementation strategies, roles of facilitators and the need for evaluation.

It is believed that a proper synchronization or coordination of facets of the curriculum model by non-formal education programmes providers and those concerned with the implementation of the Millennium Development Goals programmes will facilitate a speedy achievement of the Millennium Development Goals.

\section{Conclusion}

The paper explores the relevance of non-formal education curriculum to the implementation of the Millennium Development Goals. The paper examines the focus of each of the goals and proposed a non-formal education curriculum contents for a successful implementation and achievement of the Millennium Development Goals in Nigeria by 2015 .

\section{References}

Adewale, L. (1998). Adult Education and the promotion of indigenous knowledge and skill. In Omolewa, M and Osuji E. (Eds) Retrospect and Renewal: The State of Adult Education Research in Africa, Dakar, Senegal: UNESCO.

Akintayo, M.O., \& Oghenekohwo, J.M. (2006). Improved resource allocation to non-formal education in Nigeria and the challenges of the 2015 EFA and MDGS Expectations. Adult Education in Nigeria (NNCAE) 11, 157-173.

Akpama, S.I., \& Arikpo, A. (2002). Vocational adult education curriculum and unemployment reduction in Nigeria. African Journal of Education Research. 8, (1\&2)15-21.

Akpama, S.I. (2000). Mobilizing illiterate parents towards effective implementation of the universal basic education scheme. International Journal of Research in Basic and Life Long Education. 1, (1\&2), 232-238.

Azikiwe, U. (1992). Women education and empowerment, Nsukka: Falladu Publishing Company.

Bhola, H.S. (1980). Curriculum development for functional literacy and non-formal education programmes. Bonn: The German Foundation for International Development.

Biao, I. (2006). Networking universal basic education commission (UBEC) and national mass education commission (NMEC) for successful implementation of the universal basic education in Nigeria, Calabar: University of Calabar Press.

Biao, I. (2008). Attainment of the millennium development goals through educational reforms: A roap map for Nigeria. In B.G. Nworgwu (Eds). Educational reform and the attainment of the millennium development goals: The Nigeria experience. Nsukka: University Trust Press.

Bopp, M. (1992). Four worlds of nature, health promotion programme final reports, Ottawa: Health Conferences Carrida.

Buchert, L. (2003). Financing adult education: Constraints, and opportunities Bonn,:Germany DVV. 
Chambers, R. (1998). Rural development, putting the last first: London: Longman.

Coombs, P., \& Manzor, A. (1974). Attacking rural poverty: How non-formal Education can help. Baltimore: John Hopkins University Press.

Coombs, P. (1973). New Patterns to learning for Rural children and youth. New York: International Council for Educational Development.

Economic Commission for Africa (2005). For all MDGS 1-8. [Online] Available: http://www.commission for Africa.org/English/about/timeline-pages/timeline15may05.htm. (May 17, 2010)

Economic Commission for Africa (2006). An overview of evidence. [Online] Available: http://www.commissiovafrica,org/english/about/meetings/irst trends and evdence.df. (June 22, 2010)

Fasokun, T.O. (2006) The United Nations millennium development goals in perspective. Adult Education in Nigeria. 13, 21-43 Federal Republic of Nigeria (2004) National policy on education. Abuja: Government Press.

Harbison, F. (1973). Human resources as the wealth of nations. New York:

Illich, I. (1973). Deschooling society. New York: Harper and Row.

Kleis, R. (1992). Towards a contextual definition of non-formal education. East Lansing: Department of Agricultural Economics Michigan State University.

Labonte, R. (1998). Empowerment notes on community and professional Dimensions, Toronto: Publishing Company.

Nwabuko, L.O. (2006). Developing a model for adult education programmes delivery to achieve millium development goals in Nigeria. Adult Education in Nigeria (NNCAE) 11. 76-85. Oxford University Press.

Preece, J. (2009). Conceptual framework for non-formal Education and poverty, in J. Preece (ed). Non-formal education, poverty reduction and life enhancement: A Comparative study. Botswana: Lightbooks Limited.

UNESCO (2006). Synergies between formal and non-formal Education: An overview of good practices, Bonn: UNESCO/UIE. 
Table 1. Non-Formal Education Curriculum Contents for the Implementation of the Millennium Development Goals.

\begin{tabular}{|c|c|c|c|c|}
\hline GOALS & $\begin{array}{l}\text { Source(s) of } \\
\text { Non-Formal } \\
\text { Education } \\
\text { Curriculum }\end{array}$ & Curriculum Contents & Location & Providers \\
\hline $\begin{array}{l}1 \\
\text { emphasizes the } \\
\text { eradication of } \\
\text { extreme poverty } \\
\text { and hunger }\end{array}$ & $\begin{array}{l}\text { Functional literacy, } \\
\text { vocational education } \\
\text { Agricultural } \\
\text { extension etc. }\end{array}$ & $\begin{array}{l}\text { Skill acquisition } \\
\text { income/wealth creation }\end{array}$ & $\begin{array}{l}\text { NFE centres, Vocational } \\
\text { education centers }\end{array}$ & $\begin{array}{l}\text { Government, } \\
\text { NGOs, education } \\
\text { and financial } \\
\text { Institutions and } \\
\text { Individuals }\end{array}$ \\
\hline $\begin{array}{l}2 \\
\text { focuses on } \\
\text { achieving } \\
\text { Universal } \\
\text { primary } \\
\text { education }\end{array}$ & $\begin{array}{l}\text { Adult literacy } \\
\text { programmes, post } \\
\text { literacy programme } \\
\text { workshops \& } \\
\text { conferences }\end{array}$ & $\begin{array}{l}\text { Reading, writing } \\
\text { Arithmetic skills }\end{array}$ & $\begin{array}{l}\text { Adult education } \\
\text { entres/community centres }\end{array}$ & $\begin{array}{l}\text { Government } \\
\text { NGOs, } \\
\text { Institutions } \\
\text { individual } \\
\text { partners }\end{array}$ \\
\hline $\begin{array}{l}3 \\
\text { seeks to } \\
\text { promote gender } \\
\text { equality and } \\
\text { empower } \\
\text { women }\end{array}$ & $\begin{array}{l}\text { Education } \\
\text { programme on } \\
\text { Gender issues } \\
\text { workshops } \\
\text { conferences and } \\
\text { seminars }\end{array}$ & $\begin{array}{l}\text { Issues on how to } \\
\text { guarantee gender equality } \\
\text { political education, health } \\
\text { education, vocational } \\
\text { Home economic skills } \\
\text { etc. }\end{array}$ & $\begin{array}{l}\text { Legislation, seminars, } \\
\text { conferences, literacy and } \\
\text { Vocational education } \\
\text { centres, religious and } \\
\text { political organizations. }\end{array}$ & $\begin{array}{l}\text { Government } \\
\text { individuals, } \\
\text { NGOs, political } \\
\text { parties, religious } \\
\text { and women } \\
\text { organizations. }\end{array}$ \\
\hline $\begin{array}{l} \\
\text { Reducing child } \\
\text { mortality }\end{array}$ & $\begin{array}{l}\text { Family health } \\
\text { education, family } \\
\text { life and population } \\
\text { education }\end{array}$ & $\begin{array}{l}\text { Information and skills on } \\
\text { child care, preventive and } \\
\text { curative measures against } \\
\text { childhood diseases }\end{array}$ & $\begin{array}{l}\text { NFE centres, hospitals, } \\
\text { primary health centers, } \\
\text { house to house visitation, } \\
\text { market, religious } \\
\text { institutions and community } \\
\text { halls }\end{array}$ & $\begin{array}{l}\text { Public health } \\
\text { officers, NGOs, } \\
\text { individuals, } \\
\text { Adults } \\
\text { educators, } \\
\text { Medical social } \\
\text { workers }\end{array}$ \\
\hline $\begin{array}{l}5 \\
\text { Improving } \\
\text { maternal health }\end{array}$ & $\begin{array}{l}\text { Family planning } \\
\text { education, } \\
\text { Education for living }\end{array}$ & $\begin{array}{l}\text { Information on family } \\
\text { planning, Existing } \\
\text { programmes on health } \\
\text { opportunities for mothers, } \\
\text { ante and post natal } \\
\text { education. }\end{array}$ & $\begin{array}{l}\text { Seminars, workshops by } \\
\text { Government health } \\
\text { workers, community health } \\
\text { workers, extension } \\
\text { workers, NGOs etc }\end{array}$ & $\begin{array}{l}\text { Government, } \\
\text { NGOs, } \\
\text { Institutions, } \\
\text { Individuals, } \\
\text { Adult educators }\end{array}$ \\
\hline $\begin{array}{l}6 \\
\text { Seeks to combat } \\
\text { HIV/AIDs, } \\
\text { malaria and } \\
\text { other diseases }\end{array}$ & $\begin{array}{l}\text { Education for living, } \\
\text { family health } \\
\text { education }\end{array}$ & $\begin{array}{l}\text { Types of diseases } \\
\text { prevention and curative } \\
\text { measures, opportunities } \\
\text { for aid, usage of } \\
\text { insecticide treated nets. }\end{array}$ & $\begin{array}{l}\text { Public enlightenment, } \\
\text { hospitals, primary health } \\
\text { care centers, schools, } \\
\text { markets, town halls etc }\end{array}$ & $\begin{array}{l}\text { Government, } \\
\text { Institutions, } \\
\text { NGOs, } \\
\text { Individuals, } \\
\text { Adult educators }\end{array}$ \\
\hline $\begin{array}{l}7 \\
\text { Environmental } \\
\text { sustainability }\end{array}$ & $\begin{array}{l}\text { Environmental adult } \\
\text { education } \\
\text { programmes }\end{array}$ & $\begin{array}{l}\text { Environmentally friendly } \\
\text { strategies to exploit } \\
\text { natural resources, waste } \\
\text { disposal strategies etc. }\end{array}$ & $\begin{array}{l}\text { Residencial quarters, } \\
\text { industries, workshops, } \\
\text { vocational schools and } \\
\text { other NFE centres. }\end{array}$ & $\begin{array}{l}\text { Government } \\
\text { Institutions, } \\
\text { NGOs and } \\
\text { Individuals }\end{array}$ \\
\hline $\begin{array}{l}8 \\
\text { Development of } \\
\text { Global } \\
\text { partnership }\end{array}$ & $\begin{array}{l}\text { Conferences and } \\
\text { workshops on } \\
\text { Globalization and } \\
\text { development } \\
\text { partnerships }\end{array}$ & $\begin{array}{l}\text { Types of partnerships and } \\
\text { conditions for partnership, } \\
\text { Existing aid agencies, } \\
\text { peace education, conflict } \\
\text { management etc }\end{array}$ & $\begin{array}{l}\text { Seminars, workshops, } \\
\text { International conference } \\
\text { centers, political and } \\
\text { religious institutions. }\end{array}$ & $\begin{array}{l}\text { Government, } \\
\text { NGOs, UNO and } \\
\text { its agencies, } \\
\text { donor agencies, } \\
\text { international } \\
\text { societies etc. }\end{array}$ \\
\hline
\end{tabular}




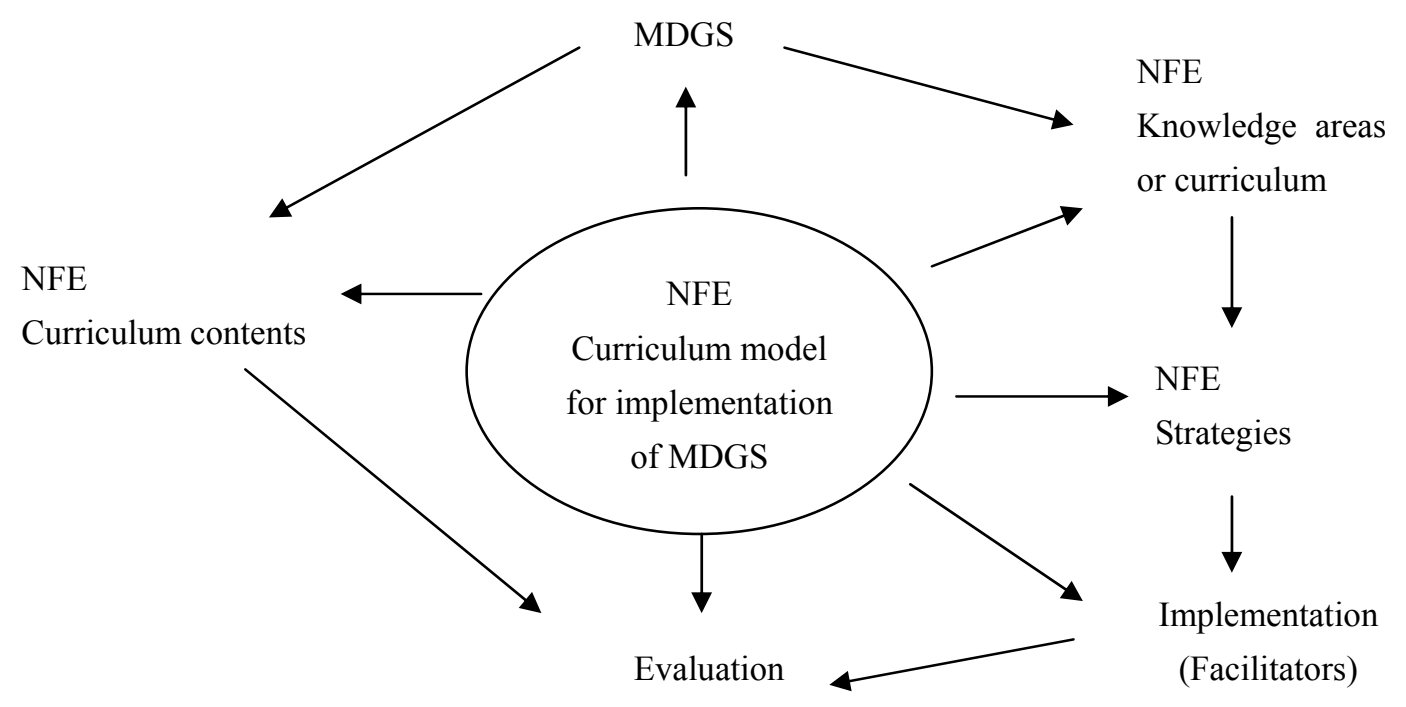

Developed by: Akpama, S.I and Adekola, G. (2010)

Figure 1. Non-formal education curriculum model for implementation of the MDGs

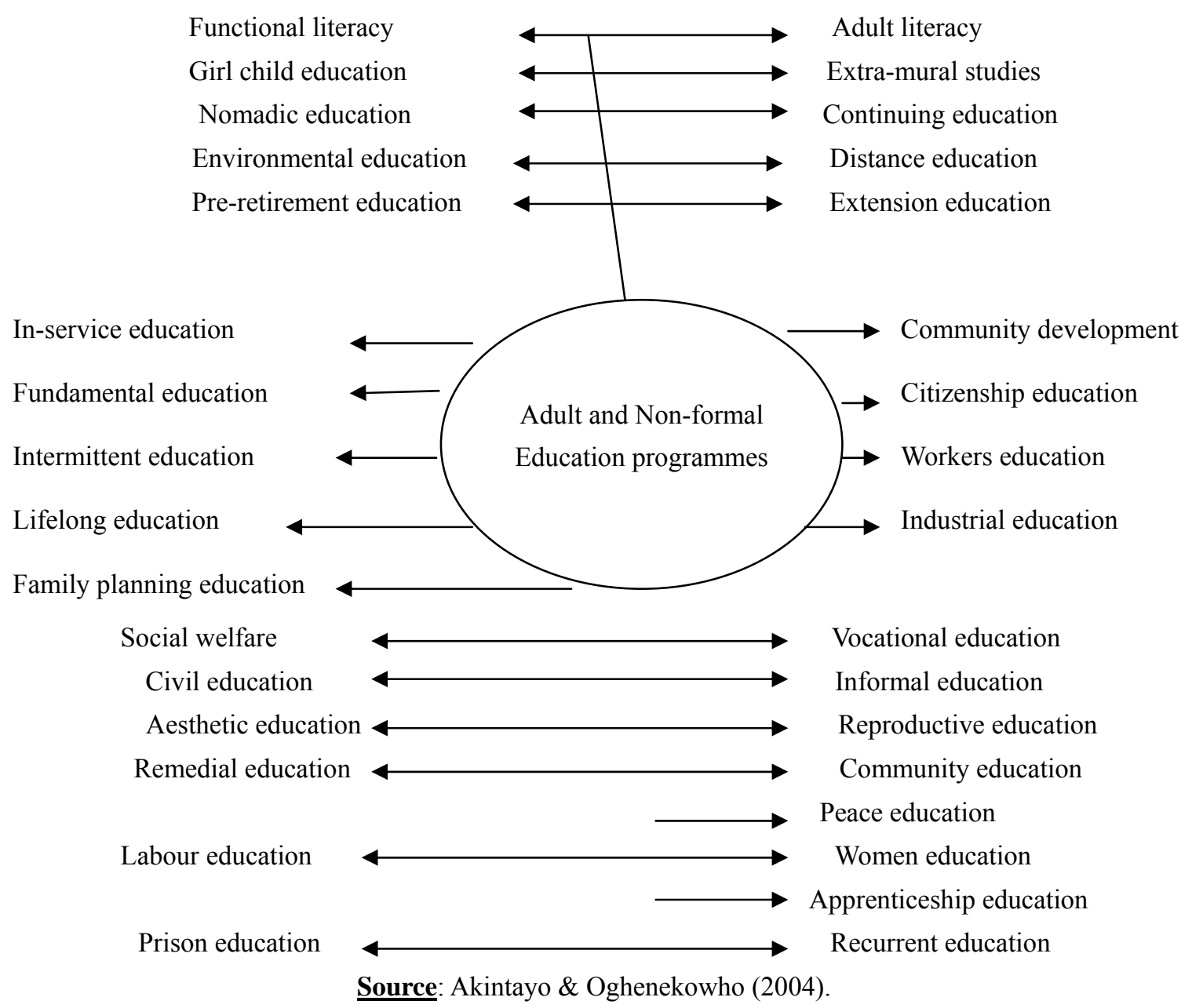

Figure 2. 